\title{
The Effectiveness of Trimetazidine Treatment in Patients with Stable Angina Pectoris of Various Durations: Results from the CHOICE-2 Study
}

\author{
Maria Glezer · on behalf of the CHOICE-2 study investigators
}

Received: January 16, 2018 / Published online: May 15, 2018

(C) The Author(s) 2018

\begin{abstract}
Introduction: Trimetazidine (TMZ) has been shown to reduce angina symptoms and to increase exercise capacity in randomized clinical trials, but more extensive data would be useful to assess its effects in real-world clinical practice and in patients with different durations of disease.

Methods: CHOICE-2 was a Russian, multicenter, 6-month, open-label, prospective observational study that assessed the effect of adding TMZ modified release $35 \mathrm{mg}$ bid to antianginal treatment in a real-world setting. The present analysis of CHOICE-2 results explored the effects of adding TMZ to background antianginal therapies with regard to the duration of stable angina.

Results: A total of 741 patients with known durations of disease were divided into four groups according to stable angina pectoris (AP) duration, ranging from less than 1 year to more than 9 years. Addition of TMZ led to a significant decrease in the frequency of angina attacks and in the use of short-acting nitrates in all
\end{abstract}

Enhanced content To view enhanced content for this article go to https://doi.org/10.6084/m9.figshare. 5873766

M. Glezer $(\bowtie)$

Department of Preventive and Emergency

Cardiology, Sechenov First Moscow State Medical

University, Moscow, Russia

e-mail: 287ast@mail.ru groups. In patients with recently diagnosed angina (AP duration < 1 year), the average number of angina attacks per week decreased significantly from $3.75 \pm 4.63$ to $0.67 \pm 1.51$ and in those with advanced disease (AP duration $>9$ years) from $5.63 \pm 5.24$ to $1.32 \pm 2.07$. Angina-free walking distance also improved significantly. Addition of TMZ also improved patient well-being. Results were achieved rapidly (within 2 weeks), were maintained over 6 months, and were obtained in all patient groups regardless of angina duration.

Conclusion: TMZ added to other antianginal therapies proved to be effective for reducing angina attacks and short-acting nitrate use, increasing angina-free walking distance, and improving patient well-being in a real-life setting, irrespective of angina duration, including patients with recently diagnosed angina. This provides an opportunity for intensification of treatment early on in the disease process, with the aim of decreasing angina burden and improving patient quality of life.

Funding: Servier.

Trial Registration: ISRCTN identifier ISRCTN65209863.

Plain Language Summary: Plain language summary available for this article.

Keywords: Antianginal combination therapy; Cardiology; Clinical practice; Observational study; Real-world evidence; Stable angina; Trimetazidine 


\section{PLAIN LANGUAGE SUMMARY}

Angina is a condition affecting more than a hundred million of patients in the world, and although treatments exist the disease is not always optimally controlled. The drug trimetazidine has previously been shown to be efficacious in treating angina. In the present study, which was conducted in real-world conditions, trimetazidine was prescribed in addition to the antianginal treatment already taken by patients. Trimetazidine was found to decrease the number of angina attacks and the use of nitroglycerine and it also improved patient walking distance and their well-being throughout the entire duration of this six-month study. This was true for all patients treated regardless of the duration of angina, which ranged from less than one year to more than nine years. These findings suggest that patients with angina could benefit from trimetazidine being adding to their treatment early on in the disease process.

\section{INTRODUCTION}

Angina pectoris (AP) is a common symptom of coronary artery disease (CAD) and affects nearly 112 million people worldwide [1]. Although annual mortality due to angina is relatively low $[2,3]$, angina symptoms are often disabling [4], thus resulting in compromised quality of life for many patients, and have considerable impact on healthcare costs [5]. Moreover, in outpatients with chronic CAD, the patients' health status (i.e., their symptoms, physical function, and quality of life) was shown to be a strong predictor of subsequent mortality and hospital admission [6]. Despite existing treatments, studies have provided evidence for variability in angina control [7-9]. They also reported discordance between physicians and patients in the assessment of angina burden, which could lead to suboptimal management $[7,9]$. These insights suggest that there is a strong need to improve angina control and to evaluate opportunities for improving quality of care throughout the patient's journey from the earliest presentation of angina. Patients' therapy should be revised at each visit to ensure reduction in angina attacks and improvement in walking distance, so as to help patients regain a good quality of life and pursue their usual activities.

Currently, few data exist on how therapy is intensified throughout the patient's journey. The Russian observational study CHOICE-2 [10], carried out by our group, evaluated the effect of adding trimetazidine (TMZ) to background antianginal therapy (beta-blockers and/or other antianginal drugs) on the frequency of angina attacks and on quality of life in patients with stable angina of various durations. TMZ modified release (MR) $35 \mathrm{mg}$ bid decreased angina attack frequency and short-acting nitrate use and increased angina-free walking distance and patient well-being [10]. Herein we report an additional analysis of the data obtained from the CHOICE-2 study, in which the effect of TMZ was assessed with regard to angina duration. The aim of the present analysis was to assess the effect of TMZ on the aforementioned parameters (angina attack frequency, short-acting nitrate use, patient-reported angina-free walking distance, and patient well-being) in patients with various durations of angina pectoris, ranging from less than 1 year to more than 9 years.

\section{METHODS}

CHOICE-2 was a 6-month, non-interventional, multicenter, open-label, prospective observational study conducted in Russia from September 2014 to September 2015 in a real-world clinical setting. Diagnosis, treatment, and inclusion were decided solely by physicians according to the medical merit and necessity of treatment with TMZ $35 \mathrm{mg}$ bid.

For the analyses presented herein, patients with known duration of disease $(n=741)$ were divided into four groups according to stable AP duration: (i) group 1, AP duration $<1$ year; (ii) group $2, \mathrm{AP}$ duration 1-4 years; (iii) group 3, AP duration 49 years; and (iv) group 4, AP duration $>9$ years.

The inclusion criteria were men and women $>18$ years of age providing their informed consent, with $\mathrm{a} \geq 3$-month history of stable angina documented by ECG-confirmed myocardial ischemia and/or prior myocardial infarction, revascularization, or $>50 \%$ coronary stenosis, 
and treated for CAD in the past month. Exclusion criteria were Canadian Cardiovascular Society (CCS) class 4 stable angina; hospitalization in the past 3 months for acute coronary syndrome (infarction or unstable angina); uncontrolled hypertension (systolic $>180 \mathrm{mmHg}$ or diastolic $>100 \mathrm{mmHg}$ ) despite ongoing antihypertensive treatment; New York Heart Association (NYHA) class III or IV heart failure; pregnancy or breast feeding; CAD surgery scheduled in the next 6 months; severe hepatic or renal failure, or other severe chronic disease requiring continuous treatment; known poor treatment compliance; intolerance or contraindications to TMZ.

Data were collected during five visits: at inclusion, at week 2 (W2) and at months 2, 4, and 6 (M2, M4, and M6). Medical history, symptoms, physical examination, and quality of life were recorded at each visit along with patient-reported walking distance eliciting angina. Walking distance was recorded by patients in a diary as the distance they walked (in meters) before experiencing angina symptoms, in conditions of daily activity, when they walked at their own pace and on mostly flat surfaces. Patients were assigned a CCS [11] and NYHA [12] class, and well-being was assessed on a visual analog scale (VAS) graded 0-100 (maximal well-being).

\section{Compliance with Ethics Guidelines}

All procedures complied with the ethical standards of the responsible committee on human experimentation (institutional and national), the 1964 Declaration of Helsinki, as revised in 2013, and the European Independent Ethics Committee. The CHOICE- 2 protocol was approved by the Inter-University Ethics Committee (protocol no. 09-14 dd. 23/10/2014; Moscow), and informed consent to inclusion in the study was obtained from all patients.

\section{Statistical Analysis}

Descriptive statistics were used for data analysis: mean and standard deviation (SD) for normally distributed continuous variables.

For qualitative and quantitative variables having few possible values, we calculated the absolute and relative incidences of each possible value. We compared quantitative variables before and after treatment within the same population or group using Student's $t$ test for normally distributed paired samples and Wilcoxon's test for non-normally distributed variables. To compare two study groups we used Student's $t$ test for independent samples in case of normally distributed quantitative variables and the Mann-Whitney test for non-normally distributed quantitative variables; we used the $\chi^{2}$ test for qualitative parameters. All tests were two-sided with a significance level of 0.05.

\section{RESULTS}

\section{Study Population}

Data from the CHOICE-2 study [10], conducted in 46 cities of the Russian Federation by 185 GPs, were used. A total of 741 patients were divided into four groups of stable AP duration: (i) AP duration < 1 year; (ii) AP duration 1-4 years; (iii) AP duration 4-9 years; and (iv) AP duration $>9$ years. Demographic and baseline characteristics are summarized in Table 1. Patients with shorter AP duration were on average younger $(60.7 \pm 8.9$ years in group 1 vs. $66.8 \pm 9.4$ years in group 4 , mean $\pm S D$ ) and had fewer comorbidities, including previous myocardial infarction, hypertension, heart failure, and diabetes. With regard to clinical parameters, angina attack frequency and shortacting nitrate use were lower in patients with AP duration $<1$ year (group 1) as compared to patients with AP duration $\geq 1$ year (groups 2, 3, and 4 ). The average number of angina attacks per week at baseline was $3.75 \pm 4.63$ in patients with more recent angina compared with $5.38 \pm 5.13,6.09 \pm 6.14$, and $5.63 \pm 5.24$ in patients in groups 2,3 , and 4 .

In all four groups, the vast majority of patients had class II or class III angina, but the proportion of patients with class III angina increased with angina duration.

Baseline antianginal treatments are shown in Table 2. Overall, patients with longer durations of AP were treated more intensively, with $40.4 \%$ of patients treated with two-drug combinations 
Table 1 Demographics and baseline characteristics of the study population $(n=741)$

\begin{tabular}{|c|c|c|c|c|}
\hline & $\begin{array}{l}\text { Group 1 } \\
(n=75)\end{array}$ & $\begin{array}{l}\text { Group 2 } \\
(n=243)\end{array}$ & $\begin{array}{l}\text { Group 3 } \\
(n=242)\end{array}$ & $\begin{array}{l}\text { Group 4 } \\
(n=181)\end{array}$ \\
\hline Age, years $\pm S D$ & $60.7 \pm 8.9$ & $60.9 \pm 7.9$ & $64.4 \pm 9.4$ & $66.8 \pm 9.4$ \\
\hline \multicolumn{5}{|l|}{ Gender, $n(\%)$} \\
\hline Male & $34(45.33)$ & $126(51.85)$ & $115(47.52)$ & $79(43.65)$ \\
\hline Female & $41(54.67)$ & $117(48.15)$ & $127(52.48)$ & $102(56.35)$ \\
\hline Body mass index $\mathrm{kg} / \mathrm{m}^{2} \pm S D$ & $30.1 \pm 4.6$ & $29.6 \pm 4.7$ & $29.7 \pm 4.7$ & $30.6 \pm 5.3$ \\
\hline \multicolumn{5}{|l|}{ Medical history and risk factors, $n(\%)$} \\
\hline Previous myocardial infarction & $22(29.33)$ & $87(35.80)$ & $82(33.88)$ & $67(37.02)$ \\
\hline Previous revascularization & $14(18.67)$ & $50(20.58)$ & $44(18.18)$ & $30(16.57)$ \\
\hline Hypertension & $64(85.33)$ & $221(90.95)$ & $234(96.69)$ & $170(93.92)$ \\
\hline Diabetes & $13(17.33)$ & $38(15.64)$ & $54(22.31)$ & $47(25.97)$ \\
\hline Heart failure & $30(40.00)$ & $157(64.61)$ & $163(67.36)$ & $119(65.75)$ \\
\hline Current smoker & $11(14.67)$ & $47(19.34)$ & $35(14.46)$ & $17(9.39)$ \\
\hline Obesity & $33(44.00)$ & $106(43.62)$ & $111(45.87)$ & $90(49.72)$ \\
\hline $\begin{array}{l}\text { Patients with } \geq 1 \text { hospitalization during } \\
\text { previous } 6 \text { months }\end{array}$ & $25(33.33)$ & $50(20.58)$ & $59(24.38)$ & $56(30.94)$ \\
\hline \multicolumn{5}{|l|}{ Clinical parameters } \\
\hline Angina attacks/week $\pm \mathrm{SD}$ & $3.75 \pm 4.63$ & $5.38 \pm 5.13$ & $6.09 \pm 6.14$ & $5.63 \pm 5.24$ \\
\hline Short-acting nitrate use/week \pm SD & $3.31 \pm 4.52$ & $5.05 \pm 5.31$ & $5.84 \pm 5.97$ & $5.59 \pm 4.59$ \\
\hline Systolic blood pressure, $\mathrm{mmHg} \pm \mathrm{SD}$ & $140.5 \pm 16.0$ & $143.2 \pm 17.3$ & $146.2 \pm 16.5$ & $141.8 \pm 16.3$ \\
\hline Heart rate, bpm $\pm S D$ & $73.3 \pm 9.9$ & $73.8 \pm 9.7$ & $76.1 \pm 10.0$ & $75.2 \pm 8.8$ \\
\hline \multicolumn{5}{|c|}{ Canadian cardiovascular society classification, $n$ (\%) } \\
\hline Class I & $4(5.33)$ & $15(6.17)$ & $11(4.55)$ & $5(2.76)$ \\
\hline Class II & $53(70.67)$ & $160(65.84)$ & $167(69.01)$ & $108(59.67)$ \\
\hline Class III & $15(2.00)$ & $60(24.69)$ & $59(24.38)$ & $62(34.25)$ \\
\hline Class IV & $1(1.33)$ & $2(0.82)$ & $0(0.00)$ & $0(0.00)$ \\
\hline \multicolumn{5}{|l|}{ Medication, $n(\%)$} \\
\hline Beta-blockers & $72(96.00)$ & $231(95.06)$ & $220(90.91)$ & $167(92.27)$ \\
\hline Calcium channel blockers & $21(28.00)$ & $85(34.98)$ & $92(38.02)$ & $59(32.60)$ \\
\hline Long-acting nitrates & $14(18.67)$ & $49(20.16)$ & $69(28.51)$ & $50(27.62)$ \\
\hline Ivabradine & $9(12.00)$ & $22(9.05)$ & $19(7.85)$ & $19(10.50)$ \\
\hline Angiotensin-converting enzyme inhibitors & $46(61.33)$ & $154(63.37)$ & $145(59.92)$ & $106(58.56)$ \\
\hline Angiotensin II receptor antagonists & $16(21.33)$ & $64(26.34)$ & $74(30.58)$ & $61(33.70)$ \\
\hline
\end{tabular}


Table 1 continued

\begin{tabular}{lllll}
\hline & $\begin{array}{l}\text { Group 1 } \\
(\boldsymbol{n}=75)\end{array}$ & $\begin{array}{l}\text { Group 2 } \\
(\boldsymbol{n}=\mathbf{2 4 3})\end{array}$ & $\begin{array}{l}\text { Group 3 } \\
(\boldsymbol{n}=\mathbf{2 4 2})\end{array}$ & $\begin{array}{l}\text { Group 4 } \\
(\boldsymbol{n}=\mathbf{1 8 1})\end{array}$ \\
\hline Statins & $70(93.33)$ & $234(96.30)$ & $230(95.04)$ & $168(92.82)$ \\
Aspirin & $61(81.33)$ & $219(90.12)$ & $206(85.12)$ & $149(82.32)$ \\
Clopidogrel & $18(24.00)$ & $30(12.35)$ & $28(11.57)$ & $20(11.05)$ \\
Diuretics & $36(48.00)$ & $115(47.33)$ & $143(59.09)$ & $107(59.12)$ \\
\hline
\end{tabular}

Table 2 Antianginal treatments at baseline

\begin{tabular}{lllcc}
\hline Medications & $\begin{array}{l}\text { Group 1 } \\
\boldsymbol{n}=\mathbf{7 5}(\mathbf{1 0 0 \%})\end{array}$ & $\begin{array}{l}\text { Group 2 } \\
\boldsymbol{n}=\mathbf{2 4 3}(\mathbf{1 0 0 \%})\end{array}$ & $\begin{array}{l}\text { Group 3 } \\
\boldsymbol{n}=\mathbf{2 4 2}(\mathbf{1 0 0 \%})\end{array}$ & $\begin{array}{l}\text { Group 4 } \\
\boldsymbol{n}=\mathbf{1 8 1}(\mathbf{1 0 0 \%})\end{array}$ \\
\hline Monotherapy & $47(62.67)$ & $131(53.91)$ & $111(45.87)$ & $88(48.62)$ \\
BB & $45(60.00)$ & $122(50.21)$ & $98(40.50)$ & $82(45.30)$ \\
CCB & $2(2.67)$ & $8(3.29)$ & $9(3.72)$ & $2(1.10)$ \\
LAN & $0(0.00)$ & $1(0.41)$ & $4(1.65)$ & $4(2.21)$ \\
Two-drug combination & $21(28.00)$ & $93(38.27)$ & $102(42.15)$ & $73(40.33)$ \\
BB + CCB & $13(17.33)$ & $61(25.10)$ & $59(24.38)$ & $41(22.65)$ \\
BB + LAN & $8(10.67)$ & $32(13.17)$ & $41(16.94)$ & $30(16.57)$ \\
CCB + LAN & $0(0.00)$ & $0(0.00)$ & $2(0.83)$ & $2(1.10)$ \\
Three-drug combination & $6(8.00)$ & $16(6.58)$ & $22(9.09)$ & $14(7.73)$ \\
BB + CCB + LAN & $6(8.00)$ & $16(6.58)$ & $22(9.09)$ & $14(7.73)$ \\
Neither BB, CCB nor LAN & $1(1.33)$ & $3(1.23)$ & $7(2.89)$ & $6(3.31)$ \\
\hline
\end{tabular}

Data are presented as number of patients with percentage in parentheses

$B B$ beta-blockers, $C C B$ calcium channel blockers, $L A N$ long-acting nitrates

in group 4 as compared to $28 \%$ in group 1 . The proportion of patients treated with monotherapy was $62.7 \%$ for patients with AP duration $<1$ year and it decreased with increasing AP durations, although the proportion of patients who were treated with monotherapy was still elevated among patients with AP duration $>9$ years $(48.6 \%)$.

\section{Effect of TMZ Add-on Therapy}

In all four patient groups, add-on treatment with TMZ MR $35 \mathrm{mg}$ bid led to a statistically significant decrease $(p<0.001)$ in mean weekly angina attacks in all groups and at all visits throughout the study duration, with significant reduction observed already after 2 weeks of treatment (Fig. 1). The average number of angina attacks per week decreased between baseline and visit M6 from $3.75 \pm 4.63$ to $0.67 \pm 1.51$ in patients with $\mathrm{AP}<1$ year and from $5.63 \pm 5.24$ to $1.32 \pm 2.07$ in patients with more advanced disease in group 4 .

With regard to short-acting nitrate use, a significant reduction was obtained in all groups at all visits (Fig. 2). The average consumption of short-acting nitrates decreased between baseline and visit M6 from $3.31 \pm 4.52$ to $0.47 \pm 1.08$ in patients with $\mathrm{AP}<1$ year and from $5.59 \pm 4.59$ 


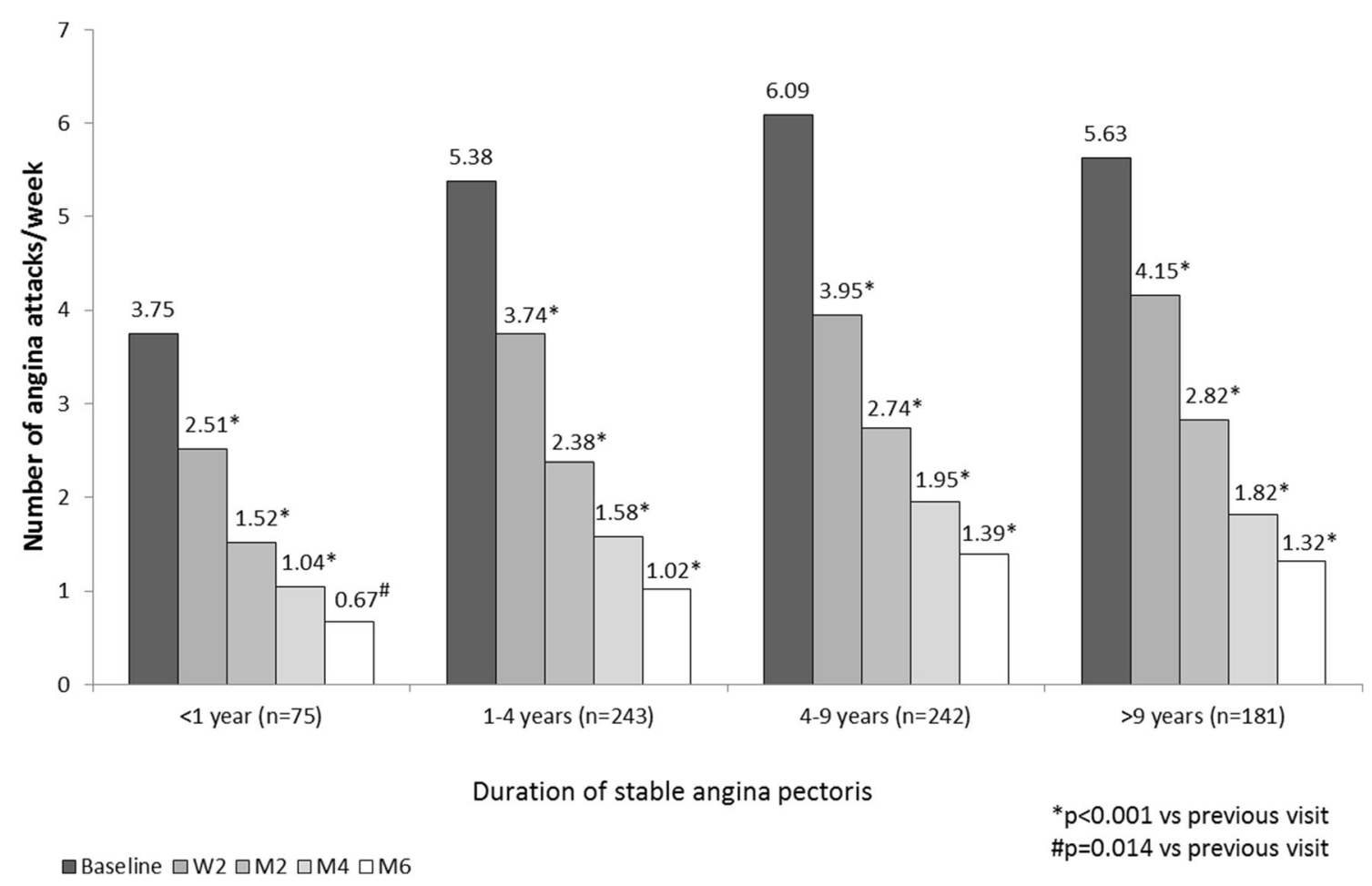

Fig. 1 Changes in mean weekly angina attacks. W2 week 2, M2 month 2, M4 month 4, M6 month 6

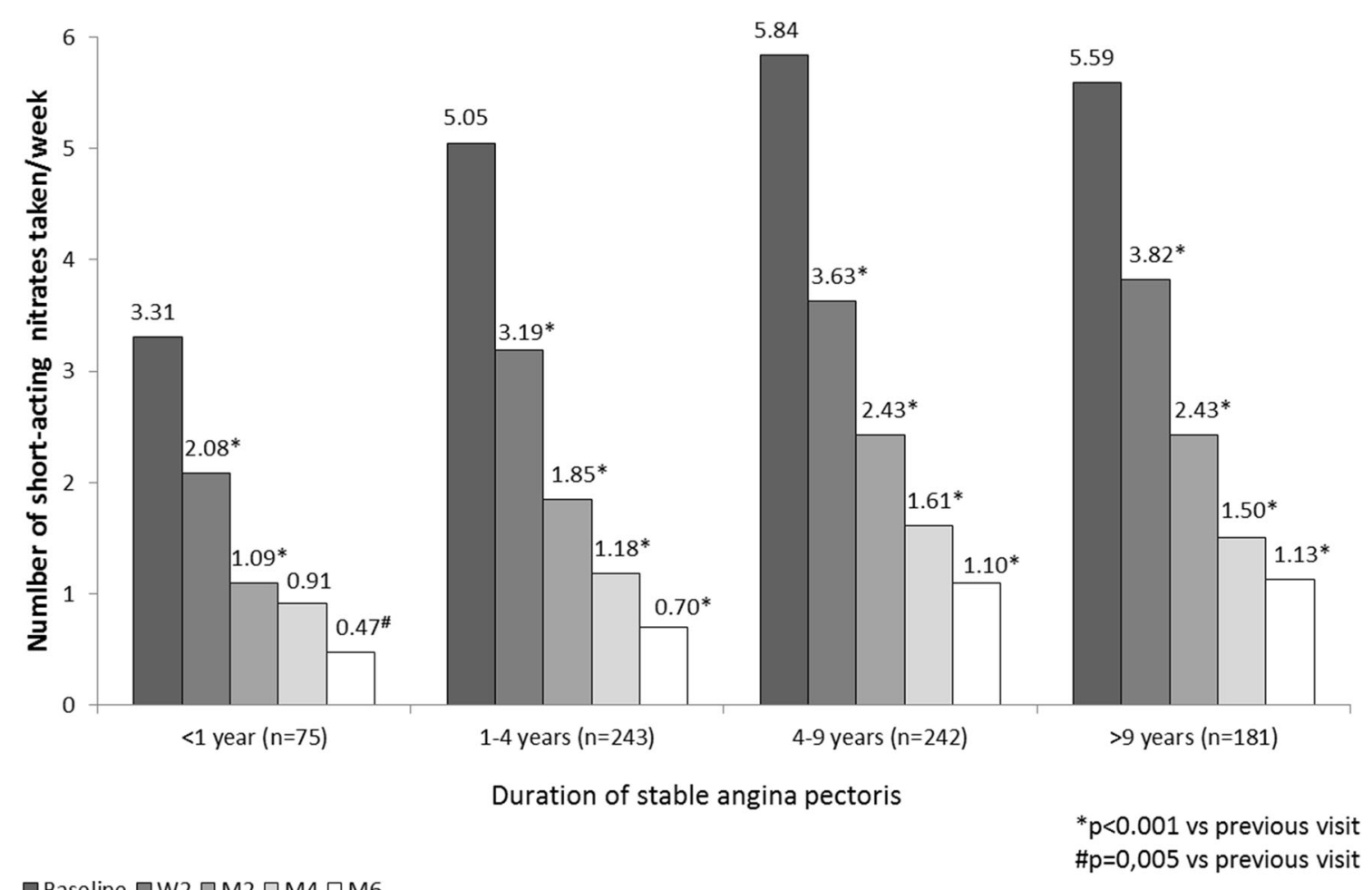

Fig. 2 Changes in number of short-acting nitrates taken per week. W2 week 2, M2 month 2, M4 month 4, M6 month 6 


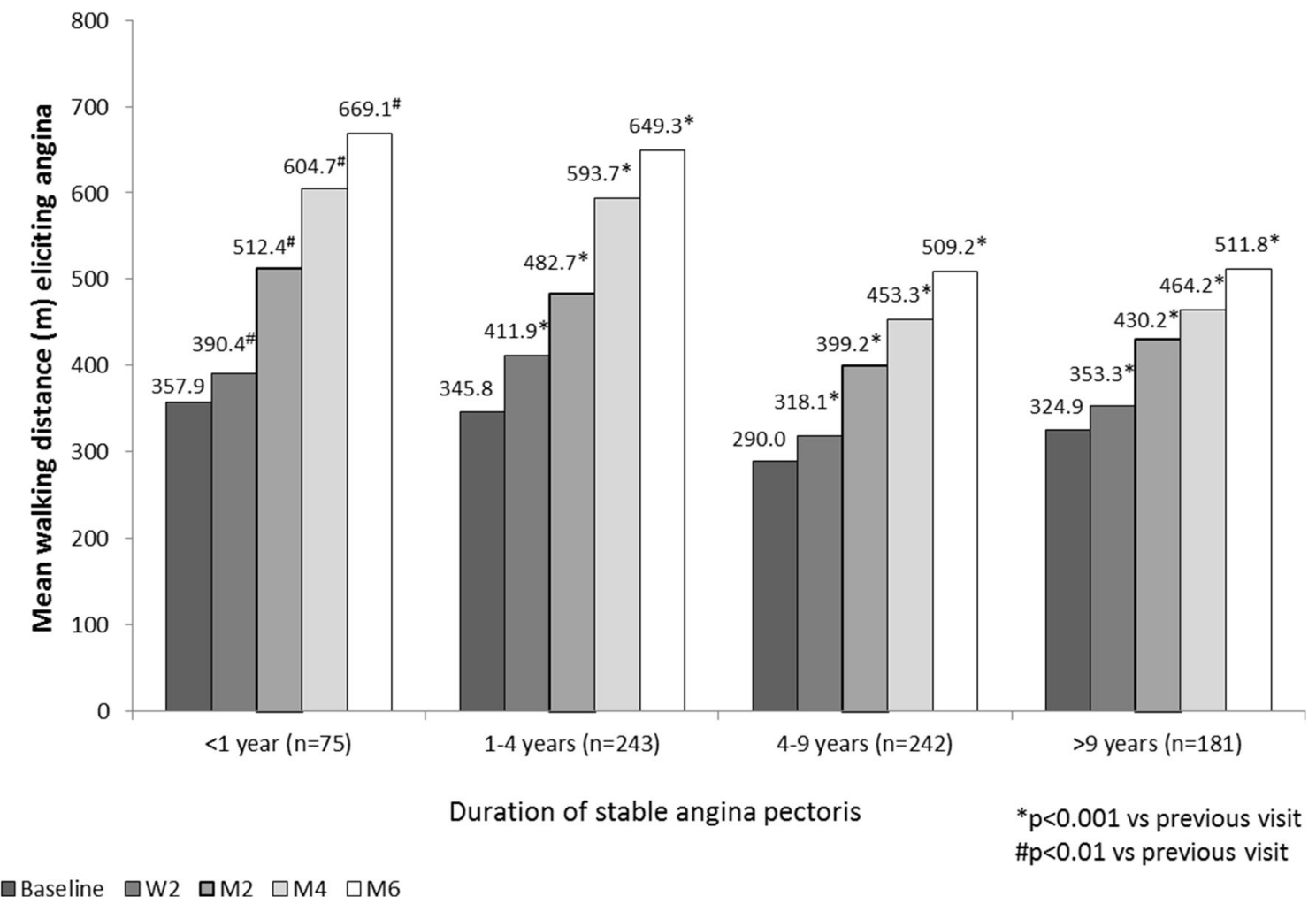

Fig. 3 Changes in mean walking distance

to $1.13 \pm 1.81$ in patients with more advanced disease in group 4.

Addition of TMZ significantly improved patient-reported walking distance in all groups throughout the study duration. Angina-free walking distance increased between baseline and visit M6 from $357.9 \pm 235.3 \mathrm{~m}$ to $669.1 \pm 484.7 \mathrm{~m}$ in group 1 and from $324.9 \pm 285.6 \mathrm{~m}$ to $511.8 \pm 337.8 \mathrm{~m}$ in group 4 (Fig. 3).

Add-on TMZ also led to improved patient well-being at all time points analyzed and in all patient groups. A significant increase in visual analogue scale was observed throughout 6 months of treatment with TMZ (Fig. 4).

\section{DISCUSSION}

In the present report, the effect of addition of TMZ was analyzed in four patient subgroups with different stable AP durations in a realworld clinical setting. We found that TMZ rapidly and significantly decreased frequency of angina attacks and short-acting nitrate use and increased angina-free walking distance and patients' quality of life in all patient groups regardless of AP duration. These effects were observed from the earliest visit (at 2 weeks) and maintained throughout the whole follow-up duration of the study (6 months).

Despite existing treatments, previous studies have shown that there is still considerable variability in achieving angina control. The Australian CADENCE study, performed in 2031 patients with chronic stable angina followed in primary care, showed that $29 \%$ of patients experienced angina at least weekly, and found marked variability in angina control across clinics [7]. Another study, APPEAR, conducted in 1257 patients from 25 US outpatient cardiology clinics found that, depending on sites, $2-24 \%$ of patients had daily or weekly angina [8]. Interestingly, just over a half of these patients were on two or more antianginal medications, suggesting that there is an opportunity for both better identification and better 


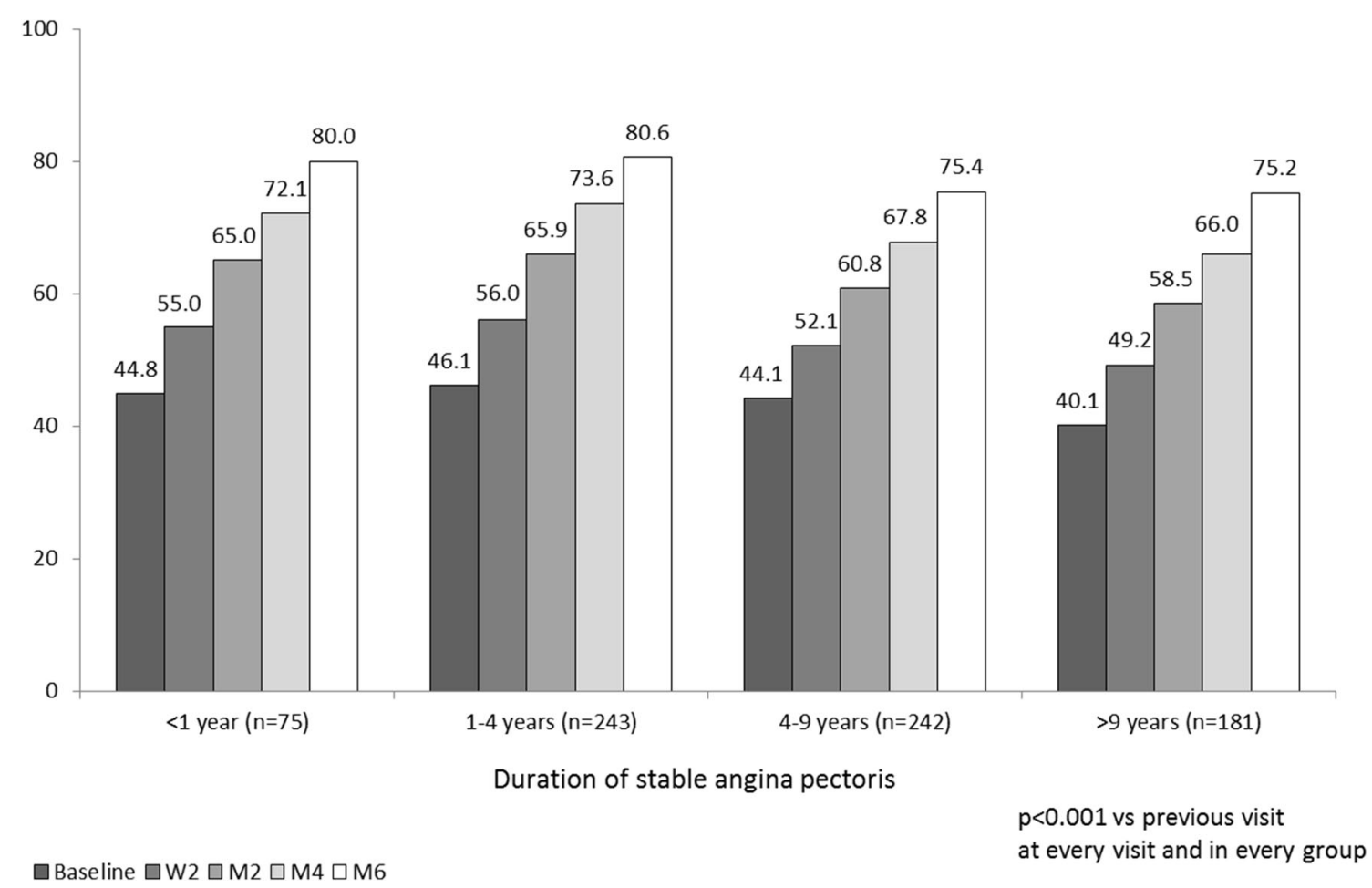

Fig. 4 Mean self-rated well-being (visual analogue scale; 0-100). W2 week 2, M2 month 2, M4 month 4, M6 month 6

management of angina. Moreover, general practitioners often underestimated the extent of angina and its impact on patients' quality of life [7]. According to the APPEAR study, $43.3 \%$ of patients with weekly angina were under-recognized by their cardiologist, and under-recognition was associated with less aggressive treatment escalation [9]. Underestimation of angina burden by physicians can therefore lead to the perception that there is no urgency in intensifying treatment, potentially resulting in a missed opportunity to improve health status in patients with compromised quality of life.

Our results are in accordance with the above findings, as in our study patients with AP durations from 1 year to more than 9 years experienced 5.38-6.09 mean weekly attacks, suggesting that angina is indeed not optimally controlled. Nevertheless, nearly half of these patients were still treated with monotherapy, even those with more than 9 years of AP duration. In those recently diagnosed with AP (AP duration $<1$ year), the proportion treated with monotherapy was $62.7 \%$. These findings suggest that optimization of angina treatment through intensification is unacceptably slow in real-life practice, despite the fact that for patients it would be important to have their symptoms controlled from the beginning of the disease. Quality of life is probably even more important for patients with recently diagnosed angina, as they are on average younger and more active; but paradoxically these are the patients who are most often treated by monotherapy.

Current guidelines [13] recommend combination of different antianginal agents in patients remaining symptomatic on monotherapy. Add-on TMZ could represent an opportunity to optimize antianginal treatment. The mechanism of action of TMZ provides an opportunity to address pathological input directly at the myocardial cell level. TMZ acts by inhibiting an enzyme involved in fatty acid oxidation, which leads to an increased creatine phosphate/ATP ratio and preservation of myocardial high-energy phosphate levels and ion pump function, ultimately translating into improved cardiac efficiency [14]. Meta-analysis of randomized controlled trials has shown the 
efficacy of TMZ in stable angina, both as monotherapy and as combination therapy [15]. Results from the CHOICE 2 study have confirmed TMZ efficacy in daily clinical practice, showing that add-on TMZ rapidly reduced angina attacks and short-acting nitrate use and improved patient well-being [10]. The present analysis further explored TMZ efficacy with regard to AP duration. It was found that TMZ effects were obtained in all patients, regardless of AP duration. The finding that add-on TMZ is beneficial for recently diagnosed patients suggests that there is an opportunity to optimize therapy and quality of life from the beginning of the patients' journey.

\section{Study Limitations}

The study has limitations inherent in the nature of its design (open-label, observational, noninterventional), which may have resulted in bias towards overestimating the treatment effect. Other limitations are the absence of a placebo group and the absence of daily dose data for the background antianginal therapies.

\section{CONCLUSION}

Addition of trimetazidine rapidly (within the first 2 weeks) and significantly decreased the frequency of angina attacks and short-acting nitrate use in patients with stable angina, increased walking distance and improved patient well-being, irrespective of angina duration, including patients with recently diagnosed angina.

\section{ACKNOWLEDGEMENTS}

Funding. Sponsorship, article processing charges and the open access fee for this study were provided by Servier, Russian Federation. Editorial assistance and article processing charges were funded by Servier, France.

Medical Writing and Editorial Assistance. Writing and editorial assistance was provided by Dr. Diana Toli of Servier.
Authorship. All named authors meet the International Committee of Medical Journal Editors (ICMJE) criteria for authorship for this manuscript, take responsibility for the integrity of the work as a whole, and have given final approval for the version to be published. All authors had full access to all of the data in this study and take complete responsibility for the integrity of the data and accuracy of the data analysis. The authors would like to thank all participating investigators for their contribution to the study.

Thanking Patients. The authors would like to thank the participants of the study.

Prior Presentations. Data presented in this manuscript were previously presented at the ICCAD conference (Venice, 2017).

Disclosures. Maria Glezer, scientific coordinator of this study, received honoraria for lectures from Servier, Moscow, Russian Federation.

Compliance with Ethics Guidelines. All procedures complied with the ethical standards of the responsible committee on human experimentation (institutional and national), the 1964 Declaration of Helsinki, as revised in 2013, and the European Independent Ethics Committee. The CHOICE- 2 protocol was approved by the Inter-University Ethics Committee (protocol no. 09-14 dd. 23/10/2014; Moscow), and informed consent to inclusion in the study was obtained from all patients.

Data Availability. The datasets analyzed during the current study are available from the corresponding author on reasonable request.

Open Access. This article is distributed under the terms of the Creative Commons Attribution-NonCommercial 4.0 International License (http://creativecommons.org/licenses/ by-nc/4.0/), which permits any noncommercial use, distribution, and reproduction in any medium, provided you give appropriate credit to the original author(s) and the source, provide a link to the Creative Commons license, and indicate if changes were made. 
Open Access. This article is distributed under the terms of the Creative Commons Attribution-NonCommercial 4.0 International License (http://creativecommons.org/licenses/ by-nc/4.0/), which permits any noncommercial use, distribution, and reproduction in any medium, provided you give appropriate credit to the original author(s) and the source, provide a link to the Creative Commons license, and indicate if changes were made.

\section{APPENDIX}

Arkhangelsk: Uskov V.L. Barnaul: Goncharenko I.I., Prasolova T.P. Belgorod: Guseva V.G., Shinkar A.S. Bryansk: Samsonova S.M. Veliky Novgorod: Vikhrova I.V., Kuz'kina S.A. Vladimir: Mitina L.V., Timofeeva I.V. Volgograd: Archakova T.M., Kovaleva N.Y., Romanova E.A., Tivon Y.V. Vologda: Antonova Y.N., Kurganova O.B. Voronezh: Davydova N.N., Klyuchantseva O.V., Popovskaya Y.V., Kharitonova E.I. Evpatoria: Kuzmina T.N. Ekaterinburg: Buzmakova K.V., Kaplenko L.I., Pospelova N.V., Stepanova A.Y. Ivanovo: Kolbasheva N.A. Irkutsk: Krasnova G.M., Pal'vinskaya A.Y., Toloknova V.A. Kazan: Bikmullina R.F., Gainullina A.A., Kedrina E.V., Mikhailova S.A., Nabiullina T.A., Nizamova A.F. Kaluga: Uskova A.A., Yushkova A.E. Kemerovo: Andreeva O.V., Fedotova G.V. Kirov: Bessergeneva O.L., Gavrilyuk D.D., Ehalo N.V., Zlobina M.V. Krasnodar: Zhemartseva E.Y., Markushina I.A., Pavlovets V.P., Sobolenko A.A. Krasnoyarsk: Apanovich I.E., Kireeva N.V., Maksimova I.V. Kursk: Butz T.V., Pavlova I.A. Lipetsk: Bachurina S.N., Orlyachenko S.V. LR Sertolovo: Zaitseva T.V., LR Lomonosov: Beznogova V.F. LR-South: Litsis N.N., Novozhenina A.Y. Moscow: Abramyan L.L., Adamyan M.M., Askerko S.N., Bolmosov A.N., Vasilieva I.N., Volodova S.I., Grishko P.V., Zherebetskaya E.S., Zemlyanaya N.S., Klyshnikova L.N., Kononchik E.I., Kuznetsova N.A., Kuz'minova I.A., Marmurova I.V., Mikhailova R.Y., Mordovina I.P., Nazarkina O.V.,
Perepechko A.P., Pivovarova N.G., Potapova T.P., Prokofiev D.A., Proniushkina N.E., Savelieva E.V., Semovskikh N.A, Timonenkova L.D., Fomin V.V., Furman O.A., Tsutsieva R.M., Chibrikina M.V., Shoshina I.N., Yashchenko E.P. Moscow region: Bocharova T.I., Demyanenko O.L., Zhukova L.B., Melnikov A.Y., Merkulieva I.A., Tyasina E.I., Pakholkova N.S., Rogozina S.V., Chugunova I.V. Murmansk: Brazhnik M.L., Guseva Y.V. Naberezhnye Chelny: Anisimova A.N., Kuzeyina S.S., Kulakhmetova R.G., Petrova I.S. Nizhny Novgorod: Ignatyeva I.A., Morozova T.A., Rybnikova N.V., Gritsenko I.I. Novokuznetsk: Kondratskaya O.V., Shishkin A.V. Novosibirsk: Gogleva N.N., Kulipanova V.M., Mitrofanova S.V., Parada E.V., Svistunova S.Y., Sergeeva T.M. Omsk: Kryukova V.V., Suprun T.N., Fedorova E.M., Shnor O.F. Orel: Mitroshina T.N., Shemetova T.S., Orenburg: Val'kevich L.P., Varnikova S.N. Penza: Ivanova E.A. Perm: Shlykova O.N. Pyatigorsk: Guryanova I.R., Zheltova V.L. Rostov-on-Don: Bulygina E.D., Gorskaya E.V., Kosenko L.V., Musaeva F.K., Fedorchenko M.Y., Harish V.I. Ryazan Region: Serbarinova O.M. Ryazan: Yatsenya Y.A. Samara: Golubev M.N., Kopaev D.E., Miludina L.A., Polischuk L.V., Shilintseva O.A., Krylova L.M. St. Petersburg: Vasilik M.V., Zotov D.D., Kalishevich N.B., Kachmazova L.I., Kontorikova S.G., Mamoshko T.A., Osnovin S.A., Timoshenko (Schmalz) I.O., Kashina A.N., Kiryanova O.G. Saratov: Kotova L.E., Kuvshinova L.E., Ulyanova I.M., Shevelo O.F. Simferopol: Kireeva I.B., Korohova L.V., Smolensk: Lisunova T.I., Medvedeva E.V. Stavropol: Matvienko T.E., Shovgaryan S.L. Stary Oskol: Nebolsina E.A. Syktyvkar: Mikusheva M.A., Misharin N.N. Tver Region: Kutaliya T.O. Tolyatti: Chernova V.N., Yanina Y.A. Tomsk: Permyakova O.V., Skurikhina N.N. Tula: Goldinova L.M., Prikhodko T.N. Tyumen: Myshyakova A.G. Ufa: Akhmerova E.Z., Zaitseva K.V., Ozerchuk A.A., Polyakova I.M., Rodionova, Safiullina I.D. Cheboksary: Arsentieva I.N., Volkova O.O. Chelyabinsk: Kondrina I.N., Kharlova T.E. Yalta: Grigorieva T.L. Yaroslavl: Kurtmulaeva K.V., Rogozina O.M. 


\section{REFERENCES}

1. Vos T, Flaxman AD, Naghavi $M$, et al. Years lived with disability (YLDs) for 1160 sequelae of 289 diseases and injuries 1990-2010: a systematic analysis for the Global Burden of Disease Study 2010. Lancet. 2012;380:2163-96.

2. Dargie HJ, Ford I, Fox KM. Total Ischemic Burden European Trial (TIBET). Effects of ischaemia and treatment with atenolol, nifedipine SR and their combination on outcome in patients with chronic stable angina. The TIBET Study Group. Eur Heart J. 1996;17:104-12.

3. Pepine CJ, Handberg EM, Cooper-DeHoff RM, et al. A calcium antagonist vs a non-calcium antagonist hypertension treatment strategy for patients with coronary artery disease. The International Verapamil-Trandolapril Study (INVEST): a randomized controlled trial. JAMA. 2003;290:2805-16.

4. Moran AE, Forouzanfar MH, Roth GA, et al. The global burden of ischemic heart disease in 1990 and 2010: the Global Burden of Disease 2010 study. Circulation. 2014;129:1493-501.

5. Arnold SV, Morrow DA, Lei Y, et al. Economic impact of angina after an acute coronary syndrome: insights from the MERLIN-TIMI 36 trial. Circ Cardiovasc Qual Outcomes. 2009;2:344-53.

6. Spertus JA, Jones P, McDonell M, Fan V, Fihn SD. Health status predicts long-term outcome in outpatients with coronary disease. Circulation. 2002;106:43-9.

7. Beltrame JF, Weekes AJ, Morgan C, Tavella R, Spertus JA. The prevalence of weekly angina among patients with chronic stable angina in primary care practices: the Coronary Artery Disease in General Practice (CADENCE) Study. Arch Intern Med. 2009;169:1491-9.
8. Kureshi F, Shafiq A, Arnold SV, et al. The prevalence and management of angina among patients with chronic coronary artery disease across US outpatient cardiology practices: insights from the Angina Prevalence and Provider Evaluation of Angina Relief (APPEAR) study. Clin Cardiol. 2017;40:6-10.

9. Qintar M, Spertus JA, Gosch KL, et al. Effect of angina under-recognition on treatment in outpatients with stable ischaemic heart disease. Eur Heart J Qual Care Clin Outcomes. 2016;2:208-14.

10. Glezer M, CHOICE-2 study investigators. Realworld evidence for the antianginal efficacy of trimetazidine from the russian observational CHOICE-2 study. Adv Ther. 2017;34:915-24.

11. Campeau L. Letter: Grading of angina pectoris. Circulation. 1976;54:522-3.

12. Criteria Committee of the New York Heart Association, editor. Nomenclature and criteria for diagnosis of diseases of the heart and great vessels. 9th ed. Boston: Little, Brown; 1994. p. 253-6.

13. Montalescot G, Sechtem U, Achenbach S, et al. 2013 ESC guidelines on the management of stable coronary artery disease: the Task Force on the management of stable coronary artery disease of the European Society of Cardiology. Eur Heart J. 2013;34:2949-3003.

14. Fragasso G, Perseghin G, De Cobelli F, et al. Effects of metabolic modulation by trimetazidine on left ventricular function and phosphocreatine/adenosine triphosphate ratio in patients with heart failure. Eur Heart J. 2006;27:942-8.

15. Danchin N, Marzilli M, Parkhomenko A, Ribeiro JP. Efficacy comparison of trimetazidine with therapeutic alternatives in stable angina pectoris: a network meta-analysis. Cardiology. 2011;120:59-72. 